Journal of Educational Research in Developing Areas (JEREDA)

Vol. 1. Issue 3, Pp. 226-239, 2020

http://www.jeredajournal.com

E-mail: info@jeredajournal.com

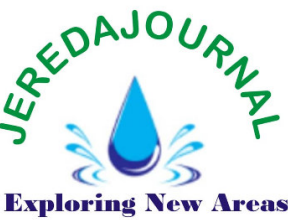

Research Article DOI: https://doi.org/10.47434/JEREDA.

eISSN : $2735-9107$

\title{
TEACHERS' ATTITUDE TOWARDS QUALITY ASSURANCE AND STANDARDS OFFICERS IN PRIMARY SCHOOLS IN EVURORE, MBEERE NORTH SUB-COUNTY, EMBU COUNTY, KENYA
}

\author{
Peter Nyaga Muchanje
}

Department of Education Management, Policy and Curriculum Studies,

Kenyatta University, Kenya.

Email: muchanje.peter@ku.ac.ke

(i) https://orcid.org/0000-0002-2377-9649

Received: $2^{\text {nd }}$ October, 2020; Revised: $11^{\text {th }}$ October, 2020; Accepted: $31^{\text {st }}$ December, 2020

\begin{abstract}
Introduction: Since the inception of school inspection in Kenya, the function of Educational Inspectors was hampered by the way inspectors executed their duties thus influencing the attitude of teachers negatively. To reduce the negative perception of teachers new practices and innovative ideas have been established through the Directorate of Quality Assurance and Standards (DQAS).

Purpose: This study aimed at finding out if teachers' attitudes have changed towards Quality Assurance and Standards Officers (QASO) since of new name and mandate

Methodology: The study used a descriptive survey research design as it was able to obtain persistent and precise information concerning the current phenomena. The sample consisted of 228 statistically sampled using the Yamen formula. A structured and open questionnaire measuring the attitude of teachers was used. To check validity, expert opinion was sought while reliability was ensured at 0.70 using Cronbach Alpha Coefficient. ANOVA and t-test method of analysis was the main statistical methods used to test the three hypotheses.

Results: The study established that female teachers had a more positive attitude towards QASO compared to their male counter parts although the difference was not significant. Further, the results revealed that a significant difference exists between more experienced teachers and less experienced teachers with less experienced teachers having a less favourable attitude towards QASO than less experienced teachers. Finally, the study found that teachers who were visited regularly had a positive attitude towards QASO compared to teachers who are not regularly visited or visited few times. In conclusion, teachers have appreciated the role of QASOs in quality education.
\end{abstract}

Recommendations/Classroom Implications: It is recommended that more frequent supervision may improve teachers' attitude for better teacher classroom performance.

Keywords: Inspection, Quality Assurance, Quality Education, Supervision, Teacher Attitude

Cite paper as:

Crossref Muchanje, P. N. (2020). Teachers' attitude towards quality assurance and Cited-by standards officers in primary schools in Evurore, Mbeere north subcounty, Embu county, Kenya. Journal of Educational Research in Developing Areas, 1 (3), 226-239. https://doi.org/10.47434/JEREDA.1.3.2020.226.

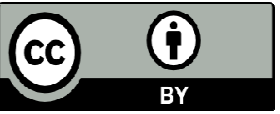

Copyright (c) 2020 The author(s) of this article retain(s) the copyright. 


\section{PUBLIC INTEREST STATEMENT}

Teachers' attitude to work is very important and plays a significant role in helping students choose and seek their interest, set goals for themselves, propel them in the right and proper directions in life. This study may benefit Ministry of Education by reminding them about the importance enough allocation of resources to Directorate of quality assurance towards improvement of quality education. The study may act as a self-assessment tool to QASOs in the effort of providing better inspection system for the purpose of improving standards.

\section{INTRODUCTION}

The idea of the inspection of schools is not new in the world of the education system. It started in France and spread to Europe and later to the whole world as a way of bringing accountability in the education system (Grauwe, 2007; Wanzare, 2002). Wilcox (2000) in a study that explored the reaction of primary school teachers, headteachers to school inspection in Britain agreed that inspection was a valuable activity in reviewing the position and the way forward in quality of education. This position was upheld by other researchers (Olulube, 2014; Ofsfed, 2014; Mwinyipembe and Orodho, 2014, 2012; and Adetula, 2010) all of who agree that inspection being an external activity in education plays vital in monitoring the education system, tracking standards, improving teachers productivity and identifying school failure.

In the United Kingdom (UK), there is a long history of inspection thoroughly documented (Ofsfed, 2014) with their main job description as being to monitor school improvement initiatives and to offer guidance in education quality without fear or favour. Ofsfed argues that the department of school inspection should be independent so as to provide non discriminative inspection. This view is supported by Ehren \& Visscher (2008) who opined that, school inspectors in England carry out systematic and timetabled classroom observation and inspection for quality control and findings published for public consumption. This means that the objectives, the process and the results are systematic and well known to all interested parties. The same schools are then visited after four years to allow for time for recommendations to be implemented (Dedering \& Muller, Volume 1, Number 3
2011). In the Netherlands, the role of inspectors is limited to supervision and provision of advice to teachers and schools. As seen by Ehren and Visscher (2008), weaker schools are visited more frequently where inspectors sit with teachers to draw action plans. This relationship improves the attitude of teachers towards the inspectors.

Although inspectors seem to be producing results in the UK. In Africa there is a lot to be done to improve teachers' confidence. In Norway, Hall (2014) supports that inspectorate department requires to establish a system for quality management which involves developing procedures evaluating and follow up results which are made public. This helps to bring the process of inspection closer to and be owned by teachers who are the main consumers. In a separate study Gaertner, Wurster and Anand (2014) opine that since inspection is process that government uses to check and improve quality of education and also shape teachers professionalism, it should be carried out in a transparent and made more consultative for good reception by the teachers.

Despite emphasis by the Nigerian Government to the Ministry of Education to take supervision seriously, (Oyesola, 2006; Ochuba, 2010 and Ololube 2014) agree that there has been inadequate inspection in schools which has made the teacher's perception towards inspection negative. As seen by Onyidoh (2007), school inspection in Nigeria faces challenges of non-adherence to inspection principles which adversely affect the quality of education and consequently teachers' attitude. Alade (2008) further posited that if education standards drop due to lack of proper insight by inspectors, then they will have 
cold reception in schools. This view was supported by Awuah (2011), who found that, one of the major causes of fallen standards of education in Ghana is weak external supervision which led to the inclusion of insection as a key factor in the education reform.

A study done by Sambirige (2009) in Uganda found that school inspection was not only threatening and stressful to teachers but also judgmental in nature. According to Sambirige, one of the contributing factors to this scenario was the fact that district inspectors did not have constructive feedback mechanisms to improve teachers' classroom practice but are filled more with power and authority. This as seen by Wanzare (2002) lead to distorted image towards the effectiveness of school inspection and the intended outcomes of education.

However, inspection seems to produce results in Botswana and Tanzania where according to Grauwe (2001), schools are informed in advance of an impending inspection. This according to Grauwe improves transparency which makes teachers consider inspectors as their co-workers and not fault finders. This notwithstanding, Matete (2009) found sentiments attributed to inspectors as unwanted visitors due to diverse reasons. In Kenya, although quality in education has been emphasized in schools, there has been a lack of confidence in the inspection process (Mwaura, 2014; Ngugi, 2014; Wasanga, 2004; Wanzare, 2002; Okumbe, 1998; Sisungo, 1988) among other researchers. That is why Ngugi (2014), Wanjohi (2007), Wanzare (2002) and Mohanty (2002), concluded that inspection of schools was authoritarial and autocratic, thus making inspection an undesired activity by teachers. The attitude of teachers must be positive if external supervision is to produce results.

The term inspector is still being used in various countries including the UK, United States, European countries, Lesotho, Senegal, and Nigeria among others in the world and still producing results, (European Commission, 2018, Wilcox (2000) and Grauwe, 2007).
However, with global demand for countries to provide and maintain quality education to respective citizens, some countries have recently developed more friendly terminologies (European Commission, (2018) and Wilcox, (2000). For example, Malawi uses "Education methods advisors", Uganda uses "teacher development advisor" while in Kenya the term inspector changed to Quality Assurance and Standards Officer (QASO), all these aimed at reducing the stigma associated with the term inspection.

Past researchers in Kenya (Mwaura, 2014; Mwangi, Mungai, Thinguri, and Makatiani, 2014; Ngugi, 2014; Wasanga, 2004; Muchanje, 2004; Wanzare, 2002 and Okumbe, 2007) concur that there has been continued mistrust between teachers and Quality Assurance Officers (QASO) previously known as inspectors in the Kenyan education system. Republic of Kenya (2000) published a handbook for inspection which was put into operation in 2005 when Quality Assurance and Standards Directorate was established to give direction on new operations in school inspection. Before the formation of the Directorate of Quality Assurance (DQAS) in 2007, it was a common belief that inspectors lacked training and had low education levels which affected their association with teachers. As a result of academic compensation, Inspectors became authoritarian who only looked for faults to pin teachers down than giving them advice. As a result, as pointed by Wanzare (2002), teachers tended to see inspection as an external imposition which warranted rejection. These opinion led to the Ministry of Education (MOE) think of strategies of making inspection more acceptable to the teachers. As a result of this rebranding, Mwinyipembe and Orodho (2014) argues that QASOs Officers have now the required training for effective job performance thus gearing to improved teachers' perception, which consequently is expected to increase teacher - QASO collaboration for improved performance.

Kenya through the Ministry of Education coined Quality Assurance and Standards Officer (QASO) to remove the 
stigma associated with the inspection as stated above (Ministry of Education, 2003). This was later enshrined legally in the Basic Education Act 2013, article 64 (Republic of Kenya, 2013), through establishment of independent Education Standards and Quality Assurance Council (ESQAC) whose mandate was follows:

1. ensure standards and maintain quality in institutions of basic education;

2. administer policies and guidelines set for basic education;

3. supervise and oversee curriculum implementation and delivery;

4. in cooperation with county education, monitor the conduct of assessments and examinations in institutions of basic education;

5. monitor and evaluate standards and quality in basic education.

This Council was to bring professionalism in the supervision of curriculum implementation in schools in the country by deploying qualified officers called QASO (Ministry of Education, 2012). Unlike Inspectors who came from headquarters to check and find faults in the curriculum policy implementation, QASO was assigned the responsibility of working with teachers to ensure that these policies are implemented in harmony. However, the operationalization of ESQAC was not fully realized since the Ministry of Education reverted back to a Directorate of Quality Assurance and Standards (DQAS) within the ministry to administer policy and guidelines, supervise and oversee curriculum implementation, monitor assessment, and examination and ensure quality and standards in the country's educational standards. Ministry of Education, Science and Technology in 2015, as a government initiative to reduce the stigma associated with school inspectors. Therefore, making inspection more result oriented than fault finding mission.

The importance of external supervision in Kenya and especially that of QASO as outline in the Basic Education Act 2013 cannot be overemphasized. The mandate of external supervision is to establish, maintain, and improve standards of education in Kenya. The supervisors are supposed to advise teachers on the best practices in education management in the process of curriculum implementation. The QASO is also supposed to visit schools regularly, conduct seminars and in-service courses as well as provide advisory services to teachers. Many researchers cited in this paper, agree that external supervision of curriculum implementation spearheaded in Kenya by QASO is a necessary activity. Earlier, external supervision popularly known as inspection which was led by the lead inspector of schools (Muchanje, 2004). The activity was characterized by threats and due consequences if things did not go the expected path. As seen separately by Wanzare, (2002) and ADEA (2003), traditional inspection borrowed to Kenya education system from British system was coercive and was based on a master-servant relationship. This activity was not productive as teachers feared the inspectors and a times treating them like small gods. Wanzare (2006) established that teachers shied off from inspectors who came for fault finding. Thus as found by Ngugi (2014) and Muchanje (2004), it was so serious that teachers would prefer to run away and answer questions of being absent rather than meet the wrath of the inspector. The implication being that the inspectors did not help teachers to perform better as they were mainly interested in reporting teachers' weaknesses without providing the necessary advice.

The performance of QASO was put in doubt in 2010 (Uwezo, 2010) when it was reported that 4 out of 100 children in class 8 could not read a class 2 level storybook in Kenya primary schools. Further, 10 out of 100 teachers were found to be absent from school on a given day. This raises the question as to whether QASO meets its mandate of supervising curriculum implementation and advising teachers on the implementation. As observed earlier, if external supervision is not regular and when it happens, quality utilization of the results is not realized, then the impact on student learning is felt. The findings by Uwezo therefore could be attributed to 


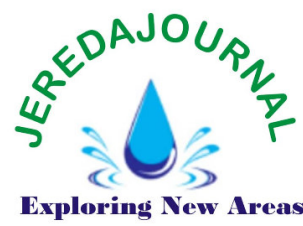

attitude that teachers have created towards the QASO.

As observed by Awauh (2011), Inspection and Supervisory services are essential elements of a system that has a direct impact on schools and teacher performance. Teachers with negative perceptions towards supervision are likely to have low job commitment, therefore, reducing productivity. This paper, therefore, endeavors to answer the question "Has the change of name from inspector to QASO helped to change teachers' attitude towards external supervision?"

\section{STATEMENT OF THE PROBLEM}

In many developing countries, the need to meet vision 2030 and Sustainable Development Goals (SDGs) through provision of quality education is an important issue that every government is grumbling with. If SDG number is not achieved, then all other goals will be a mileage. Quality education can only be achieved if QASO is strengthened and empowered to provide teachers with right support in the implementation of the curriculum.

The government of Kenya established QASO to conduct school inspection, document and share good practices in education. This was a reaction towards many complaints of inspector's ineffectiveness and an effort to improve teacher's perception about the process of inspection for improved school performance. This study therefore examines the attitude teachers have towards quality assurance and Standards Officers in Evurore, Kenya.

\section{PURPOSE OF THE STUDY}

The purpose of this study was to determine teachers attitude towards QASOs after the name changed from inspector of schools 18 years ago to Quality Assurance and Standards Officers.

\section{HYPOTHESES}

1. There is no significant mean difference in teachers' attitude towards QASO in terms of years of teaching experience in Evurore.
2. There is no significant mean difference in attitude towards QASO among male and female teachers in Evurore

3. There is no significant mean difference among primary school teacher's attitude towards QASO and the frequency of supervision by QASO $n$ Evurore

\section{METHODOLOGY}

\section{Research Designs}

The study used a descriptive survey design because according to Orodho (2009) and Creswell (2014), the design gives room for sampling people's attitudes and opinions. The design was useful for this study as it was able to obtain persistent and precise information concerning the current phenomena.

\section{Population \& Sample}

The study targeted 480 teachers distributed in 41 public primary schools in Evurore Division. To ensure inclusivity, schools in the division were stratified into four zones. Stratified random sampling was used to ensure the inclusion of all zones. In every school sampled, participants were stratified by gender and then simple random sampling was applied. The final sample consisted of 228 statistically sampled using Yamen formula for a population less than 1500 teachers teaching in primary schools in Evurore Division, Mbeere North Embu County, Kenya.

$\mathrm{n}=\mathrm{N} / 1+\mathrm{N}(\mathrm{e}) 2$

Where

$\mathrm{N}=$ Population size

$\mathrm{e}=$ level of precision

$95 \%$ is the confidence level and $p=0.5$

are assumed in this equation.

The study collected data using a structured and open questionnaire designed by the researcher guided by Frederick, Leong and Austin (2006) on attitude questionnaire development. The questionnaire was developed to obtain information on the attitude of the teachers towards QASO using a 4 point Likert scale ranging from 'strongly disagree, disagree, agree to strongly agree.' The questionnaire was divided $\mathrm{n}$ = Sample size 
into three parts: the demographic information, the teacher's level of attitude, and questions that allowed explanation.

\section{Instrument for Data Collection}

Content and construct validities of the study instrument were confirmed by 40 teachers involved in the pilot study selected from three schools in different zones in Evurore Division. These teachers were not involved in the actual study. The researcher used Cronbach's alpha to establish the internal consistency of the research instruments. Cronbach's alpha is a measure of internal consistency, that is, how closely related a set of items are as a group. A coefficient of more than 0.792 was be considered acceptable for this study according to Gay \& Hall, (2010).

Table 1. Reliability Analysis

\section{Cronbach's Alpha} .792

\section{Cronbach's Alpha Based on} Standardized Items .801

\section{$\mathbf{N}$ of Items}

\section{Procedure of Data Analysis}

To test hypotheses, charts, means, standard deviations, t-test and ANOVA method of analysis was the main statistical method used to answer the three questions.

\section{Procedure of Data Analysis}

Out of the 228 questionnaires distributed, 178 were returned representing $78 \%$ return rate, which was above average and therefore acceptable (Mugenda \& Mugenda, 2003). The responses were received from 22 head teachers and 156 teachers. Of the 178, 40 were female teachers and 138 male teachers.

\begin{abstract}
RESULTS
Teachers Years of Teaching Experience and Attitude

Hypothesis 1: There is no significant mean difference in teachers' attitude towards QASO in terms of years of teaching experience in Evurore.

The first objective of the study was to determine if teacher's attitude towards QASO in Evurore was influenced by the teaching experience. At the time of the study, the teachers' years of teaching experience were classified into five categories, as shown in Figure 1.
\end{abstract}

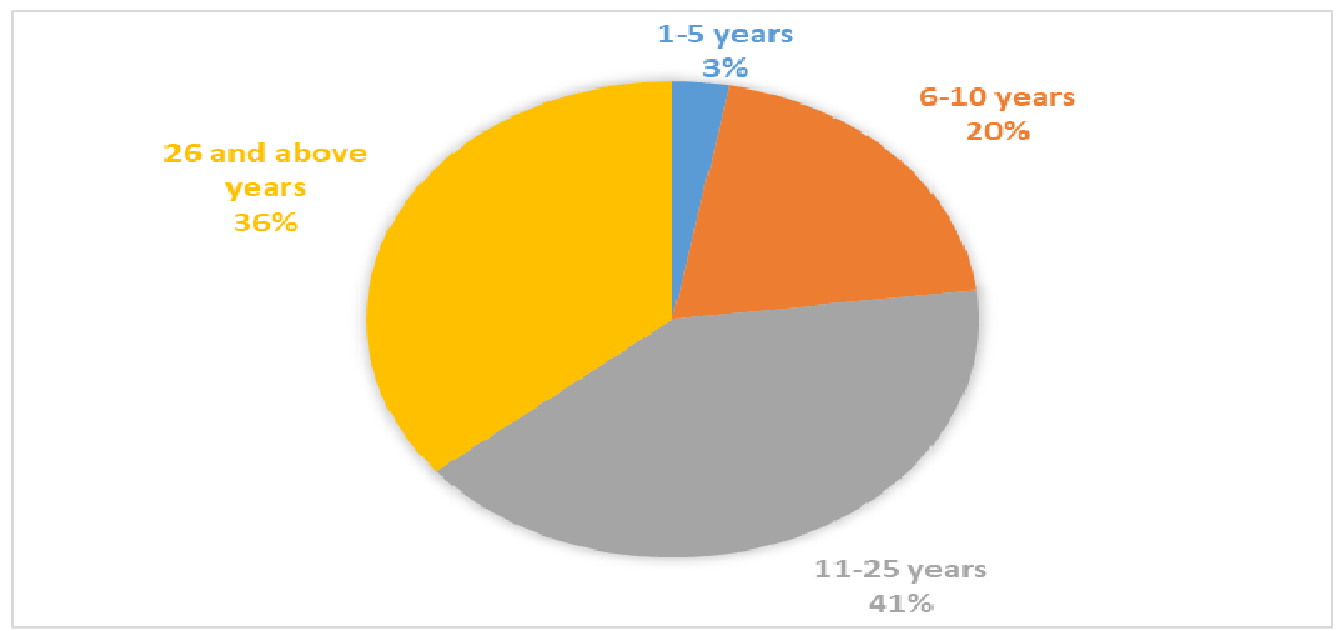

Figure 1 Teachers' experience distribution 
The data shows that Evurore division has quite an experienced group of teachers. The small proportion of teachers with an experience of 1-5 years could be due to the fact that the Ministry of Education since 2000 reduced the number of teachers being recruited by Teachers Service Commission and started employing on where the vacancy arise basis. The highest response came from teachers with an experience of 11-25 years. However, Figure 1 shows a considerable experienced population of teachers who have taught for more than 11 years. This is a population that saw the transition from inspection to QASO. It also implies that majority of teachers are about 50 years or so indicating that teachers in Evurore division are generally elderly and about to retire. This is a worrying trend because majority of teachers will exit the profession in 10 years' time.

The mean attitudes of teachers by experience in the Division are summarized in Table 2.

Table 2: Mean attitude of teachers by teaching experience

\begin{tabular}{cccc}
\hline Experience (in years) & N & Mean & $\begin{array}{c}\text { Standard } \\
\text { Deviation }\end{array}$ \\
\hline $1-5$ & 6 & 3.97 & .22 \\
$6-10$ & 36 & 3.27 & .12 \\
$11-25$ & 73 & 3.16 & .72 \\
26 AND ABOVE & 64 & 2.99 & .41 \\
TOTAL & $\mathbf{1 7 8}$ & $\mathbf{3 . 1 0}$ &. $\mathbf{3 7}$ \\
\hline
\end{tabular}

The overall mean attitude of teachers by professional experience was 3.10, which indicated that teachers agree with positively stated statements measuring attitude. This means that generally, the attitude of the teachers were positive. However, significant differences were noted between more experienced and less experienced teachers. Teachers who had taught for 11 years and above, tended to have relatively low attitude compared to teachers who had an experience of less than 11 years. The lowest attitude was those teachers who had an experience of above 26 years. In terms of variation, teachers with $11-25$ years' experience had varied perception of QASO and the most homogenous group was those with an experience of 6-10 years. The first hypothesis of the study was focused on determining if there existed any significant mean difference in teachers' attitude towards QASO in terms of years of teaching experience.

Hypothesis 2: There is no significant difference in attitude towards QASO between male and female teachers in Evurore Division

\section{Gender and Attitude of Teachers towards QASO}

The second objective of the study was to establish there were differences among teacher's gender and their attitude towards QASO. On gender status, there were 138 male and 40 female teachers representing $77.5 \%$ and $22.5 \%$ respectively of the total respondents. Given that this was rural set up which is a hardship zone (TSC, 2009), female teachers were less than male teachers which is different from areas that are not hardship. Previous studies conducted in urban areas show more female teachers compared to male teachers.

Table 3 shows the mean attitude of teachers by gender was calculated as 2.89 for male teachers and 3.92 for female teachers. Female teacher's highly positive attitude towards QASO. This means female were more prepared and ready for QASO compared to male teachers in the Evurore. This showed serious differences between teachers gender. Female teachers had more favorable attitude towards external supervision compared to male teachers from the analysis of their means. 
Journal of Educational Research in Developing Areas (JEREDA)

Vol. 1. Issue 3, Pp. 226-239, 2020

http://www.jeredajournal.com

E-mail: info@jeredajournal.com

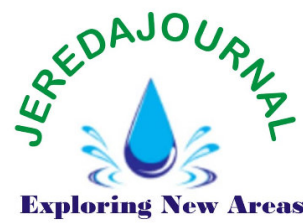

Table 3: Attitude towards QASO between male and female teachers

\begin{tabular}{lllll}
\hline & Mean & $\begin{array}{l}\text { Standard } \\
\text { Deviation }\end{array}$ & t-value & p-value \\
\hline Male & 2.89 & 0.57 & 1.068 & 0.29 \\
Female & 3.92 & 0.38 & & \\
\hline
\end{tabular}

Table 3 shows that male teachers have a lower mean than female teachers. However, t-test analysis show that the difference is not significant $t(58)=1.07$, $\mathrm{p}=0.29$. This means that there is no difference in attitude towards QASO between male and female teachers. Therefore the null hypothesis was accepted.

Hypothesis 3: There is no significant mean difference among primary school teacher's attitude towards QASO and the frequency of supervision by QASO $n$ Evurore.

\section{Frequency of Supervision and Teachers Attitude towards QASO}

The third objective of the study was to determine if there exist any significant difference in frequency of supervision by QASO and teachers' attitude in Evurore. Teachers were asked to indicate the number of times QASO visited their schools in the last two years. Teachers mean attitude in relation to frequency of supervision are summarized in Table 3.

Table 3: Teacher's Mean attitude scores and frequency of supervision

\begin{tabular}{cccc}
\hline $\begin{array}{c}\text { No. of times supervised by external } \\
\text { supervisors }\end{array}$ & N & Mean Score & SD \\
\hline None & 28 & 2.27 & 0.14 \\
$1-2$ & 63 & 2.89 & 0.54 \\
$3-4$ & 56 & 2.91 & 0.43 \\
$5-6$ & 16 & 3.02 & 0.45 \\
$7-8$ & 10 & 3.06 & 0.42 \\
9 and above & 5 & 3.13 & 0.23 \\
Total & 178 & 2.89 & \\
\hline
\end{tabular}

Table 3 shows that mean attitude of teachers with regard to the frequency of QASO supervision. The lowest mean score was reported by those not visited at all. The mean attitude improved with increase in the number of visits until 9 and supervisions. The decline in mean attitude could be attributed to the fact that increased number of supervisions could bring in fatigue and at times not giving room for implementation of feedback by teachers. Many of these schools that were not visited at all or at least few times were the furthest at the borders of Tharaka Nithi and Kitui Counties. Overall, the study found that Volume 1, Number 3
QASO were performing their duties as expected except for a few reported instances. Attitude increased with increase in number of times QASO visited the schools for supervision. This confirms findings by Mwenyepembe and Orodho (2014) who reported that QASO style of supervision had improved to a great extend with more emphasis to advice of teachers than controlling teachers. The third hypothesis of the study was to determine if there existed any significant difference teacher's frequency of QASO supervision and their attitude towards QASO. 
Journal of Educational Research in Developing Areas (JEREDA)

Vol. 1. Issue 3, Pp. 226-239, 2020

http://www.jeredajournal.com

E-mail: info@jeredajournal.com

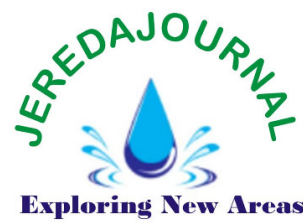

Table 4: ANOVA for Teacher's attitude Towards QASO and Frequency of Supervision

\begin{tabular}{ccccc}
\hline & Sum of Squares & df & F & Sig. \\
\hline Between groups & 3.977 & 4 & .169 & .001 \\
Within groups & 161.174 & 174 & & \\
Total & 165.214 & 178 & &
\end{tabular}

Table 4 shows $F(.169) P=0.001$ was significant at alpha $=.05$. This means that there was a significant difference between attitude of teachers and frequency of supervision. Teachers visited regularly had a more positive attitude towards QASO. This compared favorably with Mwangi (2012) who found that the more QASO visited the better relationship between them and teachers. However it disagreed with Okumbe (2007), who highlighted that due to master/servant relationship exhibited by QASO teachers, viewed their visit negatively.

\section{DISCUSSIONS}

Quality assurance and standards is one of the major strategies for monitoring teaching/learning implementation in schools. It is expected that QASO adhere to the inspection principles outlined in Basic Education Act (2013) of independence, respect of teachers, impartiality and transparency. The relationship between teachers and QASO should be collegial without exhibition of master-servant relationship.

Data analyzed indicated that there was no significant difference in attitude towards QASO among teachers in terms of their teaching experience with $\mathrm{F}(3.45)$, $P=.026$ at $a=0.05$. The researcher therefore rejected the null hypothesis that there is no significant difference between experience of teacher and their attitude towards QASO. The null hypothesis that there exists differences in attitude towards depending on the teaching experience was adopted. This was not surprising result because researches by Wanzare (2002), Okumbe (2007), Grauwe (2007) and Matete (2009) all concluded that attitude of teachers towards inspection changed depending on the experience teachers have.

The results indicate that teachers who are newly employed have little experience work hard to prove that they can perform. These category of teachers therefore use inspection by QASO as an opportunity to learn new skills that could propel them to the aspired career progression. This category of teachers also want by all means to save their jobs. This findings contradicted findings by Rahmany,Hasam and Parhoodeh (2014) who found that teachers with teaching experience of below 10 years had negative attitude towards supervision. Attitude towards QASO decreased as experience of the teacher increased although the attitude remained relatively high. The researcher attributed the positive attitude of experienced teachers to the fact that they have been inspected many times and have been used to the process, the cordial relationship created due to regular visits and above all QASO were their colleagues in teaching before the deployment. Such unique results were found by Ochuba (2010) who studied ways of improving quality of education through effective inspection of schools in Nigeria, and found that experienced teachers had negative attitude towards inspection. The researcher therefore concluded that the change in the name from inspector to QASO and significant change in supervision had impacted positively in changing attitude of teachers. The teachers who have worked for more than 26 years are nearing retirement age. These are teachers who have gained skills in teaching and overtime learnt techniques of improving students' 
performance. This category of teachers did not see any value addition to QASO inspection process.

Open ended questions revealed overall that $69 \%$ of teachers had reported a positive attitude towards the process of quality assurance but had negative attitude towards QASO implementing the process. On cross examination, the teachers who reported this were those with less than 10 years teaching experience. The experienced teachers could be operating under stress especially after introduction of Free Primary Education (FPE) due to increased numbers of students in a classes. Another possible reason could be that these teachers took issue with qualification of QASO and their capacity to provide advice and support especially those promoted from primary section. Teachers reported that, QASO are appointed from among classroom teachers and taken through INSET training organized from time to time (Republic of Kenya, 2000). This does not really improve the relationship between QASO and teachers who see their former colleagues as unwanted and some as non-performers who had nothing to do with quality. According to Wanzare (2006) and Itindi (2000), if this is not checked, this relationship may compromise the quality of education.

To examine whether there existed a statistically significant difference in attitudes towards QASO between male and female teachers an independent $\mathrm{t}$ test revealed that female teachers had more positive attitude (Mean = 3.92) towards inspection by QASO compared to male teachers (mean $=2.89$ ). The $\mathrm{t}$ value of 1.07 , with a $P$ value of 0.29 is not significant at $a=0.05$. This indicates no differences in attitude towards QASO between male and female teachers. The researcher concluded that there was no significant difference in attitude towards QASO between male and female teachers. This agrees findings by Mwangi (2012) who found that male and female teachers do not differ in their attitudes towards QASO. However, there existed differences in means among male and female teachers with female having a more positive attitude towards QASO than male teachers. This confirmed findings by Ngugi (2014) who found that female teachers in secondary schools displayed more favorable attitudes towards QASO than male teachers.

Test on differences in teachers attitude towards QASO in relation to frequency of supervision revealed $F$ $(0.169), P=0.001$ at $a=0.05$. This meant that the null hypothesis "there is no significant difference among primary school teacher's attitude towards QASO and the frequency of supervision by QASO" was rejected and the alternative hypothesis adopted. Table 3, shows mean attitude increased with increase in the number of supervisions. This means that the more QASO supervises teachers, the more teachers develop positive attitude. Teachers regularly supervised showed positive attitude towards QASO and the process of supervision. Teachers frequently visited reported that the more QASOs interact with teachers, the more they developed listening ability and readily accepted teacher's suggestions to curriculum implementation. The supervision process gradually became more collaborative and thus improved classroom management, because teachers agree to learn more teaching strategies from QASO.

Teachers also revealed that QASO did not visit schools as frequently as expected due to large coverage and transport challenges. According to QASO guide book (2007) and Ministry of Education (2002), QASO is supposed to regularly visit learning institutions to compile reports, advising the government, access, gender, enrolment, retention, governance and staffing. Findings from Evurore Division showed 28 teachers (about 16\%) of the teachers sampled were not visited for the last two years. This means that QASO were not fulfilling their mandate as enshrined in Legal notice number 11 of 2014 in accordance to basic education act 2013 (Republic of Kenya, 2013) which QASO are supposed to visit a primary school for purposes of supervision at least once per term and secondary school at least once every three years. About $64 \%$ of 
teachers said that they were visited at least between 1 to 4 years. From open ended questions, it was found that even after these visits, there were no follow up supervision on recommendations. Some of the factors that were highlighted as a reason for irregular visit were shortage of QASO officer and acute shortage of transport facility. It came out that increased teachers attitude with increase of visits was attributed to friendly nature of QASO during discussion with teachers which contradicted findings by Okumbe (2007) who asserted that QASO were rude and bossy.

Fewer supervision means that fewer teachers are supported by QASO. Teachers were however quick to exonerate the blame to QASO saying that the Directorate of quality assurance was not adequately staffed and that the lack of independence limited the financial resource necessary to perform enough supervisions as expected. Responding to the question, "how do QASO communicate their findings?" About $76 \%$ of teachers supervised many times said that QASO are very friendly when communicating supervision report with teachers. This finding is different from previous findings by Wasanga (2004), who found that inspectors were harsh and intimidating. This finding will not only encourage teachers to be committed to their work but also make QASO have a sense of belonging when on duty. On the contrary, those not supervised and teachers supervised less than 4 times indicated that the communication style of QASO is not friendly at all. The response of this category of teachers could be attributed to the fact that they have had little interaction with QASOs and therefore associating them with insection.

Of those who had been supervised more than 4 times reported that their efforts were appreciated by QASO. Almost half $(49 \%)$ of these teachers appreciated that QASO and Teacher Professional and Development reports (TPAD) reports have neared fruits in the career. One of the deputy head teachers sampled said, "I got a promotion to the position of the deputy head teacher because of my continuous outstanding performance during supervision." This category of teachers said that the inputs received from the supervisors helped teachers to strengthen their knowledge of teaching methodology and subject content. This was closely related to what was observed by Mwenyepembe and Orodho (2014) who found that a big number of teachers agreed that QASO update teachers and improve the teachers' professionalism. Of those who had not been supervised or fewer supervisions felt that QASO visits did not add value to their career progression. One of these teachers lamented, "It is a bitter fact that only those who are correctly connected get promotions and recognition." This being an important factor of supervision, QASO should realize that regular visit to schools will impact positively on teachers attitude which may improve job satisfaction level for optimal teacher performance.

In regard areas of improving QASO quality supervision, sampled teachers intimated that QASO should visit schools and supervise teachers as many times as possible so as to set a collaborative approach to supervision. To effect this, teachers proposed that the Ministry of Education in Kenya should make ESQAC an independent body as had been proposed in the basic education act (Reublic of Kenya, 2013) so that the council can get finances directly from the exchequer.

\section{CONCLUSION}

Attitude is dynamic and permeates in all aspects of life. It is affected by variables such as experience, gender and frequency of supervision. New teachers enter the profession with preset beliefs about QASO which are likely to influence their attitude. Old teachers (both gender) similarly develop new beliefs that affect their attitude towards QASO.

The findings generally show that young and less experienced teachers perceive QASO supervision positively which is inconsistent with available literature. This could be possibly because they are recently hired and would want to keep their job. The experienced teachers 
seem to be coping with QASO supervision which is a dangerous trend.

The study concludes that as much as possible, QASO should supervise teachers at least three times per year to improve the rapport and thus impacting positively on teachers' attitude.

\section{RECOMMENDATIONS}

1. The QASOs need more profesional development to equip them with new and emerging skills in education. The improved competency will put QASOs at an advantage so that even the experienced teachers can have something to reap from their interaction.

2. It was also recommended that QASO should do supervision frequently as outlined in QASO guide book. This will be made possible if the Government commits more resources towards QASO supervision for effective monitoring of curriculum implementation. This resource mobilization will enable more and regular classroom observations practical.

Conflicts of Interest: The author declares no conflict of interest.

Acknowledgments: The author acknoledged the Sub - County Director of Education Mbeere North for allowing to conduct the survey.

\section{Disclaimer Statement}

This work is part of routine studies that was carried as followup of findings in a masters thesis done 16 years ago to check if there were changes in teachers attitude.

\section{Notes on Authors}

Peter Nyaga Muchanje is a lecturer in the Department of Education Management, Policy and Curriculum Studies, Kenyatta University in Kenya. He is a PhD holder and a member Education Management Society of Kenya (EMSK) and Women Educational Researchers of Kenya (WERK). He is interested in researches Teacher's professional Development and Organisational Cultural Intelligence.

\section{REFERENCES}

Alade, M. (2008). Current issues in education reforms: Ekiti state experience. in contemporary issues in educational management. Macmillan Nigeria Publishers Limited.

Awuah, P. (2011). Supervision of instruction in public primary schools in Ghana: Teachers' and head teachers' perspectives. Professional Doctoral Thesis, Murdock University.

Ali, M. A. (1998). Supervision for teacher development: A proposal for Pakistan. UNESCO-IIEP. http://www.ddpext.worldbank.org /Edstats/PAKpub98.pd.

Badare, T. (2007). organization and conduct of various types of school inspection. Paper Presented at a workshop for Professional Education Officers in Ondostate, held at a Akure, Ondo State, Nigeria.

Canham, P. (1993). Inspectors handbook. A guide for primary school inspection and supervision. Institute of Education Alimandu Bello University.

Creswell, J. W. (2014). Research design: Qualitative and mixed approaches. Sage Publications.

Dedering, K., \& Muller, S. (2011). School improvement through inspections? First empirical insights from Germany. Journal of Educational change, 12,301-322.

European Commission (2018) Quality assurance for school development: guiding principles for policy development on quality assurance in school educaton. Brussels, Europeen Commission

Ehren, M.. \& Visscher, A. (2008). The relationship between school inspectors characteristics and school improvement. The British Journal of Education Studies, 56 (2), 205-227.

Gay, L., \& Hall, R. (2010). Educational 
research: Competence for analysis and applications. Macmillan Publishers.

Grauwe, A. (2007). Transforming school supervision into a tool for quality improvement. International Review of Education, 53, 709-714.

Lee, J. (1997). Him and OFSTED: Evaluation or revolution of school inspection. British Journal of Educational Studies, 45 (1), 3952.

Matete, R. (2009). The impact of primary school inspection on teaching and learning in Tanzania: A case of Mbeya City District. Unpublished Master of Education thesis. Olso University.

Mugenda, O. M., \& Mugenda, A. G. (2003). Research methods, quantitative and qualitative approaches. Nairobi Act Press.

Ministry of Education Science and Technology (2015). National education sector plan volume one: Basic education programme rationale and approach 2013 2018. Republic of Kenya Government Printer.

Ministry of Education (2012). The task force in the re-alighment of the education sector to the new constitution. Government printer.

Ministry of Education Science and Technology. (2003). National action plan on education for all. Nairobi, Kenya.

Mohanty, J. (2002). Primary and elementary education. Deep and Deep Publication, PVT Itd.

Muchanje, P. N. (2004). Primary school teacher's attitude towards external supervision in Mbeere North District, Kenya. Unpublished M.Ed thesis, University of Nairobi.

Mwangi, W. S. (2012). Teachers' and principals attitudes towards school inspection in selected public secondary schools in Kenya's Nyandarua District. Unpublished M.Ed project, Egerton University.

Mwinyipembe, M. M., \& Orodho, J. A. (2014). Effectiveness of quality assurance and standards officers' school academic performance in national examinations in Nakuru

District, Kenya. Journal of Education and Practice, 5 (16), 69-80.

Mwangi, B. N., Mungai, C., Thinguri, R., \& Makatiani, M. (2014). External supervision: An examination of its impact on teaching and learning practices in secondary schools in Kijiado North Sub-county, Kenya.

Mwaura, G. (2014). The role of quality assurance and standard officers in promoting education in private secondary schools in Limuru District, Kiambu County. Unpublished M.Ed project, Kenyatta University.

Ngugi, A. (2014). Teachers perception of the role of quality assurance and standards officers in enhancing quality of secondary school education in Murang'a south sub county. Unpublished MeD thesis, Catholic University.

Ochuba, V. O. (2009). Improving the quality of education in Nigeria through effective inspection of schools.http://findarticles.com/pla rticles/miga3673/is4129.

Ofsfed. (2014). The report of her majestys chief inspector of education, childrens services and skills.www.gov.uk/government/pu blications.

Okumbe, J. A. (2007). Educational management: Theory and practice. Nairobi University Press.

Onyidoh, H. (2007). The decline of the education system in Nigeria. http://www. Hehium.com.

Orodho, A. J. (2009). Element of education and social science research methods. Kanezja Publisher.

Rahmany, R., Hasani, M. T., \& Parhoodeh, K. (2014). EFL teachers'attitudes towards being supervised in an EFL context. Journal of Language Teaching and Research, 5(2), 348-359.

Republic of Kenya. (2000). Handbook for inspection of educational institutions. Government Printers.

Republic of Kenya. (2013). Basic education act. National Council for 
Law Reporting.

Sisungo, Z. W. (1998). A study of the role of the district education officers in the management and supervision of primary school education programme in the three districts of western province.

Taylor, C. F. (1996). Monitoring education, indicators, quality and effectiveness. Cassel.

Uwezo, P. (2010). Are our children learning? Annual learning Assessment Kenya/ www.uwezo.net.w-content.

Wanjohi, S. M. (2007). Teachers and princials attitude towards school inspection in selected public secondary schools in Kenya Nyandarua District. Unpublished M.Ed thesis, Egerton University.

Wanzare, Z. O. (2006). Rethinking school inspection in the third world: The case of Kenya. http//www.Ualberta.ca/ckreber/m.

Wasanga, P. N. (2004). Kenya quality assurence in basic education 6-8 Dec 2004 Kenya position. Paper Prepared for UNESCO Nairobi Cluster Consultation.

Whitby, K. (2010). School Inspection: Recent experience in high performing Education systems. Berkshire: CFBT Education Trust. http://www.cfbt.com/evidencefore ducation/pdf/schoolinspection2pdf

Wilcox, B. (2000). Making school inspection visits more effective: The english experience. UNESCO: ILEP. 